\title{
Brief Analysis of How Universities Resolve Heavy Debt Crisis
}

\author{
Wei Zheng ${ }^{1} \&$ Xin Zhang $^{2}$ \\ ${ }^{1}$ School of Economics \& Management, Changchun University of Science \& Technology, Changchun, China \\ ${ }^{2}$ Planning and Finance Department, Changchun University of Science \& Technology, Changchun, China \\ Correspondence: Wei Zheng, School of Economics \& Management, Changchun University of Science \& \\ Technology, No. 7989 Weixing Road, Changchun 130022, China. E-mail: zwcust@163.com
}

\author{
Received: March 20, 2012 \\ Accepted: April 23, $2012 \quad$ Published: June 1, 2012 \\ doi:10.5539/ass.v8n7p136 \\ URL: http://dx.doi.org/10.5539/ass.v8n7p136
}

\begin{abstract}
In the past few years, the phenomenon of indebted school running in universities and the problem of how universities resolve the debt and overcome the debt crisis have received more and more attention from people. In the light of this phenomenon and considering the actual problems in universities, this article proposes several countermeasures and suggestions to resolve bank debt for universities.
\end{abstract}

Keywords: universities, higher education, resolve, debt crisis

After the financial crisis in Asia in 1998, some scholars proposed the suggestion that "if the amount of recruitment of students in universities within three years was increased by one time more, namely, with an increase in enrollment of 2 million, and the newly recruited students were all self-funded in a total sum, with a tuition fee of ten thousand Yuan each year and other fees of 4000 to 5000 Yuan each year, then the universities might charge 20 billion Yuan more than before and the consumption amount of students at the universities might be approximately 4 billion Yuan. Considering the indirect consumption stimulated by this amount of money, it could stimulate an investment and ultimate consumption of 100 billion Yuan or so." This suggestion was soon accepted. Ever since 1999, in response to the decision and deployment of the Party Central Committee and the State Council, great-leap-forward development of higher education has been vigorously promoted in all over the country and the scale of school running of higher education has been continuously enlarged. In addition, it was clearly specified in "The Action Program of Education Booming between 2003-2007" that was announced by the State Council and that was proposed by the Ministry of Education, "Universities should carry out the evaluation system for teaching quality in institutions of higher learning all over the country that takes five years as a cycle (Ministry of Education, 2004). In order to achieve a good evaluation result, universities should not only continue to improve themselves in terms of teaching quality, but should also enlarge investment in such hardware facilities as school environment, etc. Thus, sharp expansion in recruitment of students and evaluation on teaching quality lead to rapid decline of the amount of instrument and equipment, internship field, classroom and dormitory occupied by each student to different degrees and all the above are in urgent need to be re-purchased, constructed and expanded.

In order to adapt to the above need and under the circumstance when the government investment is limited, all the universities have no other choice but to raise funds by the various means of loaning from the banks to expand the territory, build school buildings, purchase experimental facilities and books and reference materials, bring in talents and train teachers, etc., and to expedite school construction and enhance the conditions for school running. It has been indicated by the fact that, it is true that the goal of popularization of higher education has been fulfilled, but in the meantime, the universities have also assumed a heavy debt burden. Especially in the past few years, the phenomenon of indebted school running in universities has become more and more common and a lot of university presidents are compelled to take the primary task of paying off the loan and they have no time at all to show care for improvement of the quality of teaching. So far, how to resolve the debt crisis in universities has been extremely urgent.

\section{To enlarge Investment of the National Finance and Local Government in Higher Education}

At present, universities are in debt of jumbo loan and are frequently trapped in a financial crisis just as a result of insufficient national financial and local government investment. Construction indeed requires a huge amount of funds. For the past few years, state-run universities have always been relying on financial funds allocated from the state treasury, and national financial investment and local government investment are far from keeping pace with the step of expansion in recruitment of students. Universities have weak capacity in self-raised funds and 
are far from being able to satisfy demand on funds for large scale modification and construction. Hence, the national and local government should help universities to resolve the financial crisis and pull throw the difficulties. The local government can increase the funds allocated for each student in universities of all kinds and for some universities, the local government may adopt the repayment mode of "repayment of principal by the government" and "repayment of interests by the universities". Each year, the government may arrange the special funds of bank interest subsidies for the universities and offer interest subsidies for loan of the universities according to the proportion of the loan. The government may also choose the mode of classified whole burdening. That is to say, the debts of the universities are classified into necessary teaching facilities and non-teaching building according to the property of the debts. Construction of teaching building, dining hall and dormitory that is generated by expansion in recruitment of students should not only be brought into the scope of resolution, but should also be totally repaid by the government. In addition, the country carries forward the policy that "Once you repay a debt worth of 1 Yuan, the government will award you 0.4 Yuan", which, invisibly means that the government assumes part of debt for you. Universities ought to grasp this god-given opportunity, take active measures to raise funds, repay the debt and alleviate the pressure.

\section{To Collect Finance and to Pay off the Debts with Replacement of Land}

Resolution of debt in universities in a periodical job in the field of higher education under a particular historical condition and universities are also the subject of responsibility for resolving a debt. Therefore, the universities have to abolish the ideas of "waiting, depending and asking", adhere to the strategy of running the school diligently and thriftily and put the financial strength on actively repaying the debt. However, the source for the funds in running the school for universities mainly comes from two aspects: one is the financial income and the other is the tuition and fees paid by students. Since higher education in China is different from the compulsory education, investment of the country in the funds for running the universities is merely an extremely limited part and all the remaining large amount of funds for running the universities can only be filled up by the tuition charged from students. Nonetheless, due to the sharp expansion in recruitment of students for the past successive years, the charging standard in universities is also corresponding increased, which adds to the burden of the parents of university students and poses a great potential danger. Thus, the potential is quite limited to improve the capacity of raising funds in higher education by means of increasing the tuition of students. Under such a circumstance, universities have to tap their own potential to help themselves. With the precondition that the national policy allows, the universities may choose to sell the vacant land and school building to alleviate their difficulties in repaying the funds.

\section{To Strengthen Cooperation between Universities and Enterprises and to Implement Self-relief}

Since universities put together quite a lot of experts, academics and scientific research personnel with profound scientific attainments and they have a complete range of disciplines and advanced experimental facilities, they are able to resolve some significant scientific and research brainstorm projects for enterprises. Universities are still the cradle of scientific civilization and are the center of creation of knowledge, so they possess strong soft strength and can offer technical support and talents support for enterprises.

It is a good choice for universities to strength connection with enterprises, take the path of cooperation among industries, universities and research institutions and even convert a patent of invention into productivity. This can not only economize the scientific and research investment funds of enterprises and reduce experimental risks, but can also obtain actual profits, increase scientific and research funds for universities, strengthen the scientific and research power and achieve the effects of complementing each other's advantages, sharing resources and gains profits together.

It is also an extremely feasible and effective method to make full use of conversion of scientific and research achievements to raise funds and to help oneself. In the past few years, universities in China have developed step by step a batch of high tech scientific enterprises with the orientation of the market and these high tech enterprises have initially formed scientific university enterprises with Chinese characteristics and have obtained good economic benefit and social benefit. With the overall implementation of the national scientific and innovative strategy, the competitive force of enterprises is mainly reflected on the scientific content of the products. Cooperation among universities, enterprises and scientific institutions on the basis of "win-win" will also become an important source of funds for universities.

\section{To Expand Financing Channel and to Improve the Market Financial Capacity of Universities}

It is necessary for universities to take an initiative in striving for support by the government, attempt to labor for more allocation of funds and investment by the government, positively strengthen joint school running with enterprises and foreign universities and absorb more foreign funds. Taking into consideration of the practical experiences of quite a lot of foreign universities and borrowing advanced and successful foreign experiences, it has become an important approach for universities to resort to the market operation to raise funds from the society. It can yet be regarded as a sound strategy in raising funds for universities to set up educational 
foundation association, accept donation by both domestic and foreign people from all walks of life and set up a sound social donation mechanism for higher education. In this donation mechanism, there is not only public service based higher education foundation that is aimed to the whole society, but there are also alumni resources that are fully explored and integrated so as to give full play to the financing function of alumnus for social funds of their parent universities and set up a benign and interactive development mode of alumnus for development of the universities. (Qiao Haishu \& Xu Guoxin, 2006)

So long as the policy allows, nongovernmental capital may be injected into state-run universities with a steady flow of capital since nongovernmental capital has, for a long time, been trying to itch to inject capital in higher education. With injection of nongovernmental capital, debt crisis in universities is able to be alleviated and even resolved.

Owing to injection of nongovernmental capital, universities are able to reduce their dependence on the administrative competent department in terms of finance and the space of self school running will be appropriately broadened. The essential attribute of capital necessarily requires institutes on the campus to be set up with the most effective method. What is more important, with the investment structure of higher education taking changes, both the relationship between the universities and the administrative competent department and the governance structure within the universities may have great changes accordingly. All this, to some extent, may later the pattern of administration leading in higher education for the time being. For example, a board of directors in universities that reflects the interest of investors may be set up. The board of directors is based on independent directors and the president of the universities is selected and recruited by the board of directors and is also responsible for the board of directors. All significant constructions and development projects in the universities have to be audited and discussed by the board of directors.

\section{To Take Strict Control over Expenditure and to Emphasize Profit of Capital Use}

Managing out benefit. Even though there is financial constraint in running a school, so long as the expenditure is rationally taken under control and funds are effectively arranged, the funds can still make contributions to the coordinated development of all kinds of undertakings in the universities. Under the circumstance when the universities are in debt of jumbo loan, a rational arrangement of all expenditures and funds in the universities should follow the principle of "ensuring key expenditure and strictly controlling a common expenditure" and the principle of "focusing on profit and preventing the risk". The universities are supposed to deal with the relationship between development and stability in a correct way, take under control of expenditure scale in a rational way, standardize the auditing procedure for the expenditure and reinforce the responsibility system of "one pen". In the process of utilizing the funds obtained by incurring a debt, the universities are supposed to strengthen planning management and target management of the funds from beginning to the end, highlight and emphasize capital utilization benefit, intensify internal auditing, strengthen the institutional construction and supervision system of capital utilization, regard standardization, rationality and functioning of the benefits of capital used in utilization of funds of all units and utilization of all special funds as the key point in auditing, avoid irrational expenditure and the phenomena of corruption and waste and guarantee transparency in utilization of capital.

It is necessary for universities to consolidate planning, argumentation, auditing and execution control of basic construction of the campus, strictly prohibit repeated campus construction, integrate resources, intensify management, increase the utilization rate of resources, make every penny count, do a good and active job of educational loan and enhance the collection rate of tuition fees. In addition, the universities should also determine a scientific school running guidance idea, school running goal and professional disciplinary development program and talent cultivation plan according to their own conditions and environment for school running.

\section{References}

Ministry of Education. (2004). The Action Program of Education Booming between 2003-2007, endorsed by the State Council, March.

Qiao, Haishu, \& Xu, Guoxin. (2006). Alumni Donation and Development of Institutions of Higher Education: Analyzing in the View of Social Capital. Education Science, (10).

Shuai, Xiangzhi, \& Xu, Jiaming. (2009). Prevention of Indebted School Running by Regular Institutions of Higher Learning and Redemption Countermeasures. Contemporary Educational Science, (13).

Wu, Daguang. (2007). Rational Reflection and Resolving Strategy on University Loan. Educational Research, (4).

Zhou, Yuehua. (2006). Discussion on Development of Institutions of Higher Learning through Raising a Loan and Risk Control. China Higher Education, (6). 